\title{
XCV. The rate of decay of the radioactivity of polonium
}

\author{
J. W. Waters B.Sc. A.R.C.S.
}

To cite this article:J. W. Waters B.Sc. A.R.C.S. (1910) XCV. The rate of decay of the radioactivity of polonium, Philosophical Magazine Series 6, 19:114, 905-906, DOI: 10.1080/14786440608636872

To link to this article: http://dx.doi.org/10.1080/14786440608636872

曲 Published online: 21 Apr 2009.

Submit your article to this journal $\sqsubset \pi$

Џ Article views: 4

Q View related articles $\sqsubset$ 


\section{$\left[\begin{array}{ll}90.5 & 0\end{array}\right.$}

XCV. The Rate of Decay of the Radisactivity of Polonizm. By J. W. Waters, B.Sc., A.R.C.S.*

DOLOnIUM is generally regarded as identical with 1 radium $\mathrm{F}$, one of the products of the disintegration of radium. The nature of the product of disintegration of polonium is a matter of considerable interest. If the product is a solid substance it will accumulate in the course of time, and if it is radioantive its presence will be shown by the deviation of the curve of decay of radioactivity of the polonium from an exponential curve. The rate of decay of radioactivity of a specimen of polonium about five years old has been found during the past few months. Taking the age as five years the activity of the specimen was about $\frac{1}{1000}$ of its initial activity. The rate of decay was found to be nearly the same as that found by Mme. Curie for the initial rate.

The polonium was in the form of a thin deposit on a rod of bismuth. This was mounted inside the case of a gold-leaf electroscope, and the time taken by the image of the goldleaf to move over a given range of the field of view of the observing microscope was determined at intervals of a few weeks.

Let the time of transit of the gold-leaf be $\mathrm{T}$ seconds. The time taken by the gold-leaf to fall over the same range before the polonium was present was about 12 hours = 43,000 seconds. Then, the radioactivity at any time is proportional to $\frac{1}{T}-\frac{1}{43,400^{\circ}}$. The values are given in the following table. Each is the mean of several observations :-

\begin{tabular}{|c|c|c|}
\hline No. of days. & T. & $\begin{array}{c}\text { Radioactirity. } \\
\sigma\end{array}$ \\
\hline & & \\
\hline 0 & sec. & 10000 \\
20 & 799 & $91 \cdot 07$ \\
21 & 876 & $90 \cdot 72$ \\
51 & 879 & $79 \cdot 11$ \\
81 & 1005 & $67 \cdot 61$ \\
86 & 1171 & $66 \cdot 77$ \\
96 & 1185 & $64 \cdot 58$ \\
114 & 12.44 & $59 \cdot 27$ \\
123 & 1331 & $56 \cdot 74$ \\
\hline
\end{tabular}

* Communicated by the Hon. R. J. Strutt, F.R.S.

Phil. Mag. S. 6. Vol. 19. No. 114. June 1910. $3 \mathrm{~N}$ 
A curve has been drawn showing the relation between $\log \sigma$ and the number of days since the beginning of the

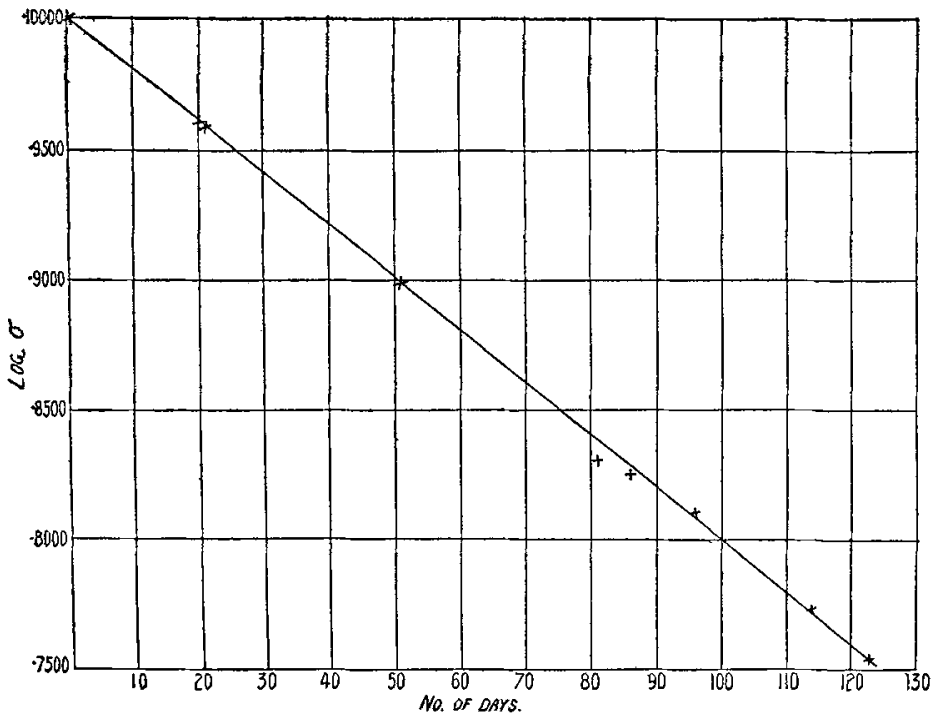

experiment. From the curve it is found that the activity falls to half value in 148 days. This differs slightly from the initial value which is giren by Mme. Curie as 140 days, but the accuracy of the experiment is not sufficient to justify any deduction therefrom.

I have to thank Prof. Strutt for suggesting this experiment and for the loan of the polonium.

XCVI. The Decay of Waves in a Canal. By W.J. HARRIson, M.A., Fellow of Clare College, Cambridge*.

TN Dr. Houstoun's reply $\dagger$ to my paper $\ddagger$ it is clearly evident 1 that his main contention must be wrong. It is necessary for the validity of his argument that waves of the type $\sin \frac{q \pi x}{a} \sin \frac{r \pi y}{b}$, and those of the type $\sin \frac{q \pi x}{a} \cos \frac{r \pi y}{b}$ should have different periods and rates of decay (moreover, that waves of the type $\sin \frac{q \pi x}{a} \cos \frac{r \pi y}{b}$ should have the same

* Communicated by the Author.

$\dagger$ Phil. Mag. [6] vol. xix. pp. 205-206 (1910).

f Phil. Mag. [6] vol. xviii. pp. $483-491$ (1909). 